\title{
Challenges and Prospects for Agricultural Greenhouse Gas Mitigation Pathways Consistent With the Paris Agreement
}

OPEN ACCESS

Edited by:

Robert Martin Rees,

Scotland's Rural College,

United Kingdom

Reviewed by:

Mark Van Wijk,

International Livestock Research

Institute, Kenya

Jules Bayala

World Agroforestry Centre, Kenya

*Correspondence:

Sinead Leahy

sinead.leahy@nzagrc.org.nz

Specialty section:

This article was submitted to

Climate-Smart Food Systems,

a section of the journal

Frontiers in Sustainable Food Systems

Received: 30 September 2019

Accepted: 23 April 2020

Published: 22 May 2020

Citation:

Leahy S, Clark $\mathrm{H}$ and Reisinger A (2020) Challenges and Prospects for Agricultural Greenhouse Gas Mitigation Pathways Consistent With

the Paris Agreement.

Front. Sustain. Food Syst. 4:69.

doi: 10.3389/fsufs. 2020.00069

\author{
Sinead Leahy*, Harry Clark and Andy Reisinger \\ New Zealand Agricultural Greenhouse Gas Research Centre, Palmerston North, New Zealand
}

Global emissions pathways that would limit warming to 1.5 or well below $2^{\circ} \mathrm{C}$, consistent with the temperature goal of the Paris Agreement, rely on substantial reductions of agricultural greenhouse gases (methane and nitrous oxide) along with reaching net zero carbon dioxide emissions from fossil fuels. Failure to reduce agricultural emissions would require even more rapid cuts of carbon dioxide emissions and could jeopardize the ability to limit warming to $1.5^{\circ} \mathrm{C}$. Modeled pathways that achieve the necessary agricultural emission reductions do so by pricing agricultural emissions. However, there is a large gap between such model scenarios and reality when it comes to the agricultural sector. To date, no single country currently exposes agricultural emissions to any mandatory carbon price and current evidence suggests considerable reluctance to the application of other climate policies with comparable stringency to agriculture. A more realistic view is needed if we are to avoid modeled emission scenarios providing an overly optimistic picture of mitigation potentials from the agricultural sector. There are entry points for mitigation of agricultural greenhouse gases outside government price policies, but many questions remain around their scalability and efficacy. A comprehensive and accelerated effort will be needed to bridge the gap from modeled emissions to realistic policy pathways.

Keywords: agriculture, mitigation, greenhouse gas, Paris agreement, emissions

\section{MODELS AND REALITY FOR GLOBAL AGRICULTURE MITIGATION}

The recent IPCC Special report on Global Warming of $1.5^{\circ} \mathrm{C}$ (IPCC, 2018) details a wide range of global emission pathways that would achieve the temperature goal of the Paris Agreement but they all include substantial reductions in agricultural greenhouse gases (methane and nitrous oxide) below forecast baseline trends (Huppmann et al., 2018). An earlier analysis by Wollenberg et al. (2016) suggested a global target for reducing non- $\mathrm{CO}_{2}$ emissions from agriculture of $\sim 1 \mathrm{Gt}^{\mathrm{CO}_{2} \text { - }}$ eq below baseline by 2030 to limit warming in 2100 to about $2^{\circ} \mathrm{C}$ above pre-industrial levels. The IPCC database of scenarios that limit warming to 1.5 or well below $2{ }^{\circ} \mathrm{C}$ indicate greater median reductions well in excess of $2 \mathrm{GtCO}_{2}$-eq below baseline by 2030, with further significant reductions beyond. The most ambitious scenarios assessed by the IPCC (2018) that limit warming to $1.5^{\circ} \mathrm{C}$ with limited or no overshoot reduce global agricultural emissions by $16-41 \%$ (interquartile range) in 2050 relative to 2010 , whereas baseline emission increase by $24-54 \%$ over the same period. This amounts to a median reduction of direct global agricultural non- $\mathrm{CO}_{2}$ emissions of $4.8 \mathrm{Gt}^{\mathrm{CO}_{2} \text {-eq }}$ below baseline by 2050 (Huppmann et al., 2018; Frank et al., 2019). 
These ambitious mitigation pathways achieve the necessary emission reductions by applying prices of typically several hundred US\$/ $/ \mathrm{CO}_{2}$-eq by 2050 to agriculture as well as the energy sector. Some apply more than US\$100/tCO $2^{-}$ eq by 2030 to all emissions sources, at least in developed countries (Kriegler et al., 2014; Riahi et al., 2017), and assume concurrent supply-side mitigation; reductions in demand due to dietary change and reduced food loss and waste (IPCC, 2018, 2019).

However, there is a large gap between such model scenarios and current reality. While there is increasing adoption of price-based policies to address energy, transport, and industry related $\mathrm{CO}_{2}$ emissions, these policies do not yet cover these sectors comprehensively and often do not reflect the carbon prices implied in the above scenarios. Moreover, no single country currently exposes agricultural emissions to any mandatory carbon price or other climate policies with comparable stringency. Wollenberg et al. (2016) estimated that currently feasible reductions, even if agriculture were exposed to a global emission price of US\$20/tCO $2^{-}$ eq, would deliver only $0.2-0.4 \quad \mathrm{GtCO}_{2}$-eq abatement by 2030 .

While elimination of carbon dioxide emissions remains the global priority, failure to concurrently reduce global agricultural emissions would make limiting warming to $1.5^{\circ} \mathrm{C}$ by 2050 all but impossible even if action on fossil carbon dioxide emissions were to accelerate dramatically. It is wellestablished that constraining global temperatures to any level allows only a finite amount of carbon dioxide to be emitted. For example, for a 50/50 chance of limiting warming to $1.5^{\circ} \mathrm{C}$, the remaining allowable carbon budget is about 580 $\mathrm{GtCO}_{2}$, hence the urgent need to reduce global annual carbon dioxide from currently more than $41 \mathrm{GtCO}_{2}$ to net zero by 2050 (IPCC, 2018).

However, this carbon budget of $580 \mathrm{GtCO}_{2}$ is contingent on a substantial concurrent reduction of agricultural emissions. If agricultural emissions were to remain constant, rather than decline as in the modeled pathways to $1.5^{\circ} \mathrm{C}$, the warming from those additional emissions would reduce the allowable carbon budget by about another $250 \mathrm{GtCO}_{2}$ (Rogelj et al., 2015, 2018; Allen et al., 2016). Achieving global net zero $\mathrm{CO}_{2}$ emissions by 2050 already presents an enormous challenge; accomplishing this target even earlier is not a realistic prospect. The interactions between more or less ambitious reductions of agricultural emissions and allowable carbon dioxide emissions are illustrated in Figure 1.

The stark conclusion is that significant reductions of direct agricultural emissions over the next three decades is not an optional contribution but a necessary component of efforts to limit warming to $1.5^{\circ} \mathrm{C}$. Failure to achieve such reductions would mean exceeding this temperature limit even if all other sectors maximize their efforts, or would increase reliance on carbon dioxide removal through largescale afforestation or use of bioenergy along with carbon capture and storage, which in itself presents risks to food security (IPCC, 2019).

\section{CURRENT PROSPECTS FOR ACTION ON AGRICULTURAL EMISSIONS}

The required scale of global reductions cannot be driven by cobenefits alone but will incur real costs somewhere to someone. As noted by the IPCC in its recent report, "the full mitigation potential assessed in this report will only be realized if agricultural emissions are included in mainstream climate policy" (Hurlbert et al., 2019).

While substantial reductions in agricultural emissions could in theory be achieved through the widespread introduction of price-based policies, or through equally ambitious regulations or other measures with an implicit price, current evidence suggests considerable reluctance to apply stringent climate policies to agriculture even in developed countries. While more than 100 countries have included agriculture mitigation in their Nationally Determined Contributions (Richards, 2019), New Zealand is currently the only country actively considering a compulsory price on agricultural emissions. The option was discussed recently but rejected in Ireland (Joint Committee on Climate Action, 2019). New Zealand has a strong incentive to apply mainstream climate policy instruments to its agricultural emissions, given that more than $48 \%$ of its gross emissions originate from this sector (MfE, 2018).

New Zealand's experience provides a salutary lesson in the difficulties of pricing agricultural emissions. New Zealand's policy discussions on agricultural emissions began in the midnineties during negotiations on the Kyoto Protocol, which New Zealand ratified in December 2002. In 2003, the New Zealand Government proposed a compulsory agricultural emissions research levy on farmers to accelerate the search for mitigation solutions while exempting the sector from exposure to an emissions price. Dubbed the "fart tax," the proposal was met with fierce opposition and replaced by a voluntary joint industrygovernment research investment in return for an exemption from an emissions price. In 2008, New Zealand introduced the first emissions trading system in the world designed to cover all economic sectors and Kyoto gases but delayed entry of agriculture until at least 2012. In 2012, given the perceived absence of cost-effective mitigation options and lack of commensurate actions by New Zealand's competitors, entry of agriculture into the emissions trading scheme was deferred indefinitely. More recently, New Zealand's Interim Climate Change Committee recommended that agricultural emissions should be priced with a farm level emissions pricing levy/rebate scheme being implemented by 2025 (ICCC, 2019). This is currently being considered by the New Zealand Government as part of a broader Zero Carbon Bill which it hopes to have in place by the end of 2020, but there is fierce debate about the level of methane reduction New Zealand should aim for by 2050, which would influence the price that agricultural methane emissions are exposed to.

New Zealand's example illustrates two decades of unresolved grappling with the complexities of addressing agricultural emissions via price-based policies against a background of understandable concerns about their effectiveness, potential 

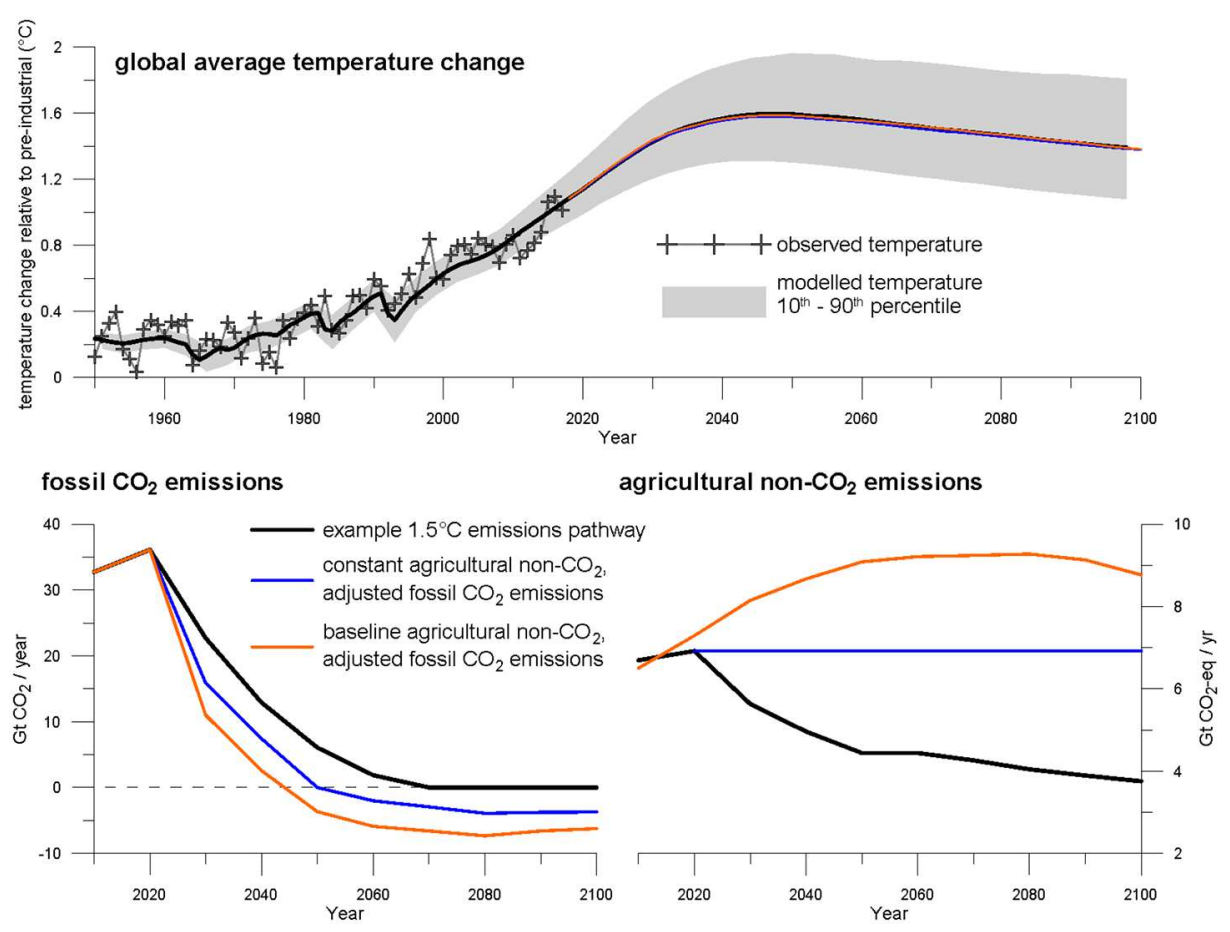

FIGURE 1 | Three alternative global pathways of fossil $\mathrm{CO}_{2}$ and agricultural non- $\mathrm{CO}_{2}\left(\mathrm{CH}_{4}\right.$ and $\left.\mathrm{N}_{2} \mathrm{O}\right)$ emissions consistent with global warming of $1.5^{\circ} \mathrm{C}$. The lower panels show fossil $\mathrm{CO}_{2}$ (left panel) and agricultural non- $\mathrm{CO}_{2}$ (right panel) emissions. The black line shows an illustrative global emissions pathway that would limit warming to $1.5^{\circ} \mathrm{C}$ with limited $\left(0.1^{\circ} \mathrm{C}\right)$ overshoot. The red line shows an emissions pathway where agricultural non- $\mathrm{CO}_{2}$ emissions are not mitigated, i.e., follow a baseline projection, and fossil $\mathrm{CO}_{2}$ emissions are adjusted downwards to result in the same global average temperature change from all gases throughout the twenty-first century, including through negative emissions from about 2045 onwards. The blue line shows an intermediate pathway where agricultural non- $\mathrm{CO}_{2}$ emissions are held constant from 2020 onwards and fossil $\mathrm{CO}_{2}$ emissions are again adjusted to produce the same overall global average temperature change. Emissions and removals of all other gases, and for $\mathrm{CH}_{4}$ and $\mathrm{N}_{2} \mathrm{O}$ from other sectors, follow the same unchanged illustrative $1.5^{\circ} \mathrm{C}$ mitigation pathway in all three scenarios. The top panel shows observed (HadCRUT4: Morice et al., 2012) and modeled global average temperatures for all three pathways (probabilistic median and 10-90 percentile range, using MAGICC; Meinshausen et al., 2009, 2011).

social and economic impacts on farmers, loss of international competitiveness, and the risk of emissions leakage from such a policy (e.g., Federated Farmers, 2018).

Some other countries have adopted specific GHG emission targets for agriculture, or targets for gases generally not covered by existing emissions trading schemes, such as the target of $30 \%$ reduction in non-ETS emissions across the EU by 2030 . However, policies targeting specific climate outcomes in agriculture remain underdeveloped (Henderson and Frezal, 2019; OECD, 2019a). Some countries have implemented market-based offset schemes for agricultural emission sources (e.g., Australia, California, several Canadian provinces) but their voluntary nature limits their uptake and efficacy (Henderson and Frezal, 2019). More stringent agricultural climate policies are hampered by concerns about loss of competitive advantage in the absence of global coordination and associated risk of emissions leakage (Blandford and Hassapoyannes, 2018).

If developed countries are finding it challenging to implement price-based or stringent regulatory policies targeting agricultural greenhouse gas emissions, most developing countries will find such policies even harder to implement given concerns about food security and self-sufficiency, and rural poverty (Mbow et al., 2019). This view is supported by modeling studies (e.g., Hasegawa et al., 2018) that concluded climate change mitigation actions could have potentially adverse side effects on food security for some populations. Many of the negative consequences arising from blunt price-based policies could be avoided by more nuanced implementation and targeted support mechanisms for vulnerable groups (Fujimori et al., 2018; Roy et al., 2018; Loboguerrero et al., 2019), but the question arises whether finance, governance and institutional capacity exist along with political will to deliver such complex policy arrangements at the necessary scales (Grewer et al., 2018).

Novel agricultural mitigation technologies, such as inhibitors (Hristov et al., 2015; Di and Cameron, 2017) or vaccines (Wedlock et al., 2013), are not generally represented in mitigation pathways by integrated assessment models (Rogelj et al., 2018). This means that some future mitigations might become easier to achieve, or emission reductions could be even more significant than envisaged in those modeled pathways. However, the efficacy and adoption of such technologies remains speculative at this stage and will likely be limited to specific production systems. Even if highly efficacious, adoption of such technologies will still depend on financial incentives or regulatory requirements from governments or companies. 
Achieving agricultural mitigation pathways in line with $1.5^{\circ} \mathrm{C}$ pathways is thus likely to require integrated policy interventions spanning supply and demand approaches (IPCC, 2019). International coordination is critical to address concerns about competitiveness, ensure environmentally effective outcomes and avoid perverse consequences at the trans-national scale (Blandford and Hassapoyannes, 2018). Agricultural trade is subject to a wide range of barriers and distortionary subsidies that reflect powerful special interests as well as developing countries' desire for food self-sufficiency and protection from food price spikes, some of which have been linked to increased biofuel demand driven by climate policies in the energy sector of developed countries (Tadesse et al., 2014; Anderson, 2016; OECD, 2019b). This means that increasing concern about climate change will not necessarily translate into more ambitious and coordinated mitigation policies in agriculture. A more realistic view is needed of feasible and socially, as well as politically, sustainable agriculture policies to avoid modeled emission scenarios providing an overly optimistic picture of mitigation potentials.

\section{ENTRY POINTS FOR MITIGATION IN AGRICULTURE OUTSIDE GOVERNMENT POLICIES}

In the current absence of ambitious agricultural mitigation policies from national governments, are there prospects for action from other actors? We suggest that there are, but whether these will drive meaningful reductions in global emissions remains an open question.

Governments are potentially being outflanked by targets and requirements set by large international food companies, whose on-farm supply chain emissions often account for significant proportions of their total GHG footprint. For example, 57.4\% of Danone's scope 3 GHG emissions are related to the purchase of agricultural products i.e., due to milk buying (Danone, 2017). Many international food and beverage companies (Table 1) are setting ambitious emissions targets and increasingly mandating even their suppliers to provide a product that meets the company's stated climate goals. Total GHG emissions from livestock supply chains are estimated at around $7.1 \mathrm{Gt} \mathrm{CO}_{2} \mathrm{eq} / \mathrm{yr}$ (Gerber et al., 2013). A report on the GHG emissions of 35 of the world's largest meat and dairy companies suggest that these companies could be responsible for up to $1 \mathrm{Gt} \mathrm{CO}_{2} \mathrm{eq} / \mathrm{yr}$ (14\%). A major source of emissions for these companies are those that come from their on-farm supply chains (GRAIN the Institute for Agriculture Trade Policy, 2018). These company goals, alongside global market dynamics, will increasingly shape production systems of the future. However, while this approach may influence internationally traded products it may have limited impact on subsistence and small-holder farmers that in many developing countries provide more than half of total food production (Rapsomanikis, 2015). Rough estimates suggest that small-holder farming contributes agriculture sector emissions of about 1.7 Gt $\mathrm{CO}_{2}$ eq/yr (Vermeulen and Wollenberg, 2017).
TABLE 1 | Greenhouse gas targets for selected major food companies.

\begin{tabular}{|c|c|c|}
\hline Company & Base year & Target \\
\hline Danone & 2015 & $\begin{array}{l}\text {-Reduce Scope 1, 2, and } 3 \text { emission intensity by } \\
50 \% \text { by } 2030 \\
\text {-Achieve a } 30 \% \text { absolute reduction of scope } 1 \\
\text { and } 2 \text { emissions by } 2030 \\
\text {-Achieve net zero (Scope } 1+2+3 \text { ) by } 2050\end{array}$ \\
\hline Mars Inc. & 2015 & $\begin{array}{l}\text {-Reduce total emissions (Scope } 1+2+3 \text { ) } 27 \% \\
\text { by } 2025 \text { and } 67 \% \text { by } 2050 \\
\text {-Achieve net-zero GHG emissions in direct } \\
\text { operations by } 2040\end{array}$ \\
\hline Nestle & 20102014 & $\begin{array}{l}\text {-Reduce GHG emissions (Scope } 1 \text { and 2) } \\
\text { per ton of product in every product category } \\
\text { to achieve an overall reduction of } 35 \% \text { in } \\
\text { manufacturing operations vs. } 2010 \\
\text {-Reduce GHG emissions per ton of product by } \\
10 \% \text { in distribution operations vs. } 2014 \\
\text {-Reduce Scope } 3 \text { emissions by } 8 \% \text { by } 2020 \\
\text { from base year } 2014\end{array}$ \\
\hline Synlait Milk Limited & - & $\begin{array}{l}\text { Reduce emissions per kilogram of milk solids } \\
\text { on-farm by } 35 \% \text { (consisting of }-50 \% \text { nitrous } \\
\text { oxide, }-30 \% \text { methane, and }-30 \% \text { carbon } \\
\text { dioxide) and off-farm by } 50 \% \text { by } 2028\end{array}$ \\
\hline Tesco & 2015 & $\begin{array}{l}\text { Reduce Scope } 3 \text { emissions by } 17 \% \text { by } 2030 \\
\text { Reduce Scope } 1 \text { and } 2 \text { emissions } 60 \% \\
\text { by } 2025\end{array}$ \\
\hline Coca-Cola Co. & 2010 & Reduce scope $1+2+3$ emissions $25 \%$ by 2020 \\
\hline General Mills Inc. & 2010 & $\begin{array}{l}\text { Reduce absolute GHG emissions across full } \\
\text { value chain (Scope } 1+2+3 \text { ) by } 28 \% \text { by } 2025\end{array}$ \\
\hline Kellogg & 2015 & Reduce Scope 3 emissions by $50 \%$ by 2050 \\
\hline PepsiCo. & 2015 & $\begin{array}{l}\text { Reduce Scope } 1+2+3 \text { emissions by } 20 \% \text { by } \\
2030\end{array}$ \\
\hline Unilever PLC & 2010 & $\begin{array}{l}\text { Reduce emissions from the life-cycle of their } \\
\text { products 50\% per consumer use by } 2030\end{array}$ \\
\hline
\end{tabular}

Sources: www.sciencebasedtargets.org; https://www.nestle.com/csv/impact/climatechange/climate-change; https://www.synlait.com/sustainability/\#env.

Consumer choice has the potential to both drive and respond to food company climate targets. Product labeling incorporating carbon footprints is increasing but highly differentiated by markets; their effectiveness to drive actual change in behavior depends on society's broader disposition toward environmental vs. economic goals (O’Neill et al., 2015; Valdivia et al., 2015). A perceived climate friendly product may allow a producer to gain access to the high value-added product market, but evidence remains limited whether a broad enough range of consumers is willing to change consumption patterns and/or consistently pay a price-premium for products labeled as climatefriendly (Feucht and Zander, 2017). Rising awareness of the nexus between dietary patterns and human health could provide another avenue for changes in demand (IPCC, 2019) as could the potential large disruptive changes arising from synthetic meat and milk products. However, the competitiveness, sustainability, and consumer acceptance of synthetic products remains largely speculative at this point (Stephens et al., 2018; Bryant and Dillard, 2019; Lynch and Pierrehumbert, 2019). By 2050, the technical potential of dietary changes ranges from 0.7 to $8 \mathrm{Gt}$ $\mathrm{CO}_{2}$ eq/yr making it a substantial mitigation option. However, 
limited studies exist which evaluate the economic mitigation potential and plausible policy pathways for large-scale dietary change, including how to manage trade-offs with food security and livelihoods of livestock producers (IPCC, 2019).

Focusing on reducing emissions intensity via productivity improvements and addressing yield gaps is generally accepted as a useful entry point for mitigation (Shafer et al., 2011; Mbow et al., 2019), as this can simultaneously meet food security, rural development, and climate change mitigation goals (Vermeulen et al., 2012; Wollenberg, 2017). The adoption and use of best practices and technologies by the bulk of the worlds agricultural producers could result in significant reductions in emissions. The technical potential, based on a set of regional case studies, is estimated between 1.1 and $1.8 \mathrm{Gt} \mathrm{CO}_{2}$ eq (Gerber et al., 2013). However, whether reducing emissions intensity results in reductions of absolute emissions depends on changes in total production. If increased productivity is used to generate more food to meet nutritional or economic goals, absolute emissions will generally rise. Reducing emissions intensity will only reduce absolute emissions if total production does not increase at a faster rate (Gerber et al., 2013). However, recent studies suggest that in the absence of changes to technological progress, dietary patterns, food distribution and markets, agricultural, land could expand further (Bajzelj et al., 2014; Popp et al., 2017; Roos et al., 2017; Gil et al., 2019).

A focus on productivity improvement as a mitigation strategy can also have important indirect effects on emissions. Productivity improvements often reduce the cost of production and as a result, lead to additional land-use change, water use and related emissions at the margin of intensive systems (Grafton et al., 2018; Phalan, 2018). By contrast, productivity can directly support afforestation or agroforestry through land sparing/sharing if it is undertaken within a sustainability context rather than a production growth context (Ceddia et al., 2014; Cohn et al., 2014).

The success of "sustainable intensification" and emissions intensity as a metric depend strongly on whether productivity gains go hand in hand with constraints on the total amount of food produced; fewer animals, less land and lower emissions, rather than more food with the same or more land and higher emissions. The climate benefits of intensification are thus tied inextricably to concurrent and coordinated changes in food demand, dietary choices, and broader land-use policies (Yu et al., 2015; Zomer et al., 2016; Hurlbert et al., 2019; Mbow et al., 2019).

Disruptive change from novel mitigation technologies, such as methane vaccines and methane and nitrous oxide inhibitors, could produce significant global benefits but thought needs to be given early to pathways for adoption in developing countries. Most of the development of a methane inhibitor is being carried out in developed countries, with the most advanced product (3NOP) so far showing high efficacy ( $>30 \%$ reduction) in feedlot systems (Hristov et al., 2015) but limited suitability in grazing based systems (Reisinger et al., 2018). Efforts are underway to produce inhibitors suitable for grazing based systems and alternative formulations containing 3-NOP can extend the time that methane formation is inhibited (Muetzel et al., 2019) but the delivery of inhibitors to animals is likely to still rely on intensively managed systems. While detailed data on the distribution of intensive livestock production units are not readily available for most countries, rough estimates in developing countries suggest that mixed intensifying potential systems occupy 13 percent of the land area (Robinson et al., 2011). To deliver global benefits, it will be important to consider options for delivery, along with market chains and training, and means of finance, to create opportunities for success in a wider range of countries.

\section{CONCLUSION}

Achieving the temperature goal of the Paris Agreement will rely on substantial reductions in agricultural GHGs below forecast baseline trends. Current modeled pathways give an unrealistically optimistic picture of the mitigation potential from agriculture, because they all assume directly a price on emissions or actions being taken that have an equivalent shadow price. The reality is that climate policy for agriculture lags far behind climate policy in the energy sector-partly for good reasons related to food security and livelihoods, partly because vested and political interests are strong, and partly because it is a particularly challenging problem that requires coordination of action across multiple and disparate domains, ranging from nutritional health to rural economic development to biodiversity. These barriers won't go away in a hurry, and increasing concern about climate change impacts, as well as flow-on effects of climate policies in other sectors, could even harden some of those barriers. Alternative entry points for action do exist and some of them have the potential to outflank government policies and targets, but large questions remain about their scalability and efficacy. Focusing on emissions intensity is a useful entry point but its actual success in delivering emissions reductions depends strongly on a coordinated set of demand-side policies that currently are not in place. More comprehensive effort is needed to bridge the gap from modeled emissions to realistic policy pathways. Future modeling studies by the integrated assessment community would benefit from testing the consequences of bottom-up intervention strategies and technologies as outlined here and contrast them with first-best, global price-based mitigation outcomes assumed in many model studies to date. It is essential that the agricultural sector contribute to emissions reductions if the Paris agreement 1.5 or well below $2^{\circ} \mathrm{C}$ target is to be achieved. But such actions are only meaningful if efforts are upscaled significantly in the energy (fossil $\mathrm{CO}_{2}$ ) sectoragriculture can only complement but not substitute for failure to rapidly reduce $\mathrm{CO}_{2}$ emissions.

\section{AUTHOR CONTRIBUTIONS}

SL, HC, and AR conceived and wrote the paper.

\section{FUNDING}

This paper was supported by the New Zealand Agricultural Greenhouse Gas Research Centre (NZAGRC). 


\section{REFERENCES}

Allen, M. R., Fuglestvedt, J. S., Shine, K. P., Shine, K. P., Reisinger, A., Pierrehumbert, R. T., et al. (2016). New use of global warming potentials to compare cumulative and short-lived climate pollutants. Nat. Clim. Change 6, 773-776. doi: $10.1038 /$ nclimate2998

Anderson, K. (2016). "International food price spikes and temporary trade policy responses," in Agricultural Trade, Policy Reforms, and Global Food Security (New York, NY: Palgrave Macmillan US), 177-206. doi: 10.1057/978-1-137-46925-0_8.

Bajzelj, B., Richards, K. S., Allwood, J. M., Smith, P., Dennis, J. S., Curmi, E., et al. (2014). Importance of food demand management for climate mitigation. Nat. Clim. Change 4, 924-929.. doi: 10.1038/nclimat e2353

Blandford, D., and Hassapoyannes, K. (2018). "The role of agriculture in global GHG mitigation," OECD Food, Agriculture and Fisheries Papers, No. 112 (Paris: Organisation for Economic Cooperation and Development (OECD)), 126.

Bryant, C., and Dillard, C. (2019). The impact of framing on acceptance of cultured meat. Front. Nutr. 6:103. doi: 10.3389/fnut.2019.00103

Ceddia, M. G., Bardsley, N. O., Gomez-y-Paloma, S., and Sedlacek, S. (2014). Governance, agricultural intensification, and land sparing in tropical South America. Proc. Natl. Acad. Sci. U.S.A. 111, 7242-7247. doi: $10.1073 /$ pnas.1317967111

Cohn, A. S., Mosnier, A., Havlík, P., Valin, H., Herrero, M., and Schmid, E. (2014). Cattle ranching intensification in Brazil can reduce global greenhouse gas emissions by sparing land from deforestation. Proc. Natl. Acad. Sci. U.S.A. 111, 7236-7241. doi: 10.1073/pnas.1307163111

Danone (2017). Environmental Performance. Available online at: http:// iar2017.danone.com/performance-in-2017/key-performance-indicators/ environmental-performance/ (accessed December 12, 2019).

Di, H. J., and Cameron, K. C. (2017). Ammonia oxidisers and their inhibition to reduce nitrogen losses in grazed grassland: a review. J. R. Soc. N. Zeal. 48, 127-142. doi: 10.1080/03036758.2017.1354894

Federated Farmers (2018). Submission by Federated Farmers of New Zealand on the Low-Emissions Economy Issues Paper. Wellington: Productivity Commission, 15. Available online at: https://productivity.govt.nz/assets/SubmissionDocuments/988a5eedda/Sub-039-Federated-Farmers.pdf (accessed May 12, 2020).

Feucht, Y., and Zander, K. (2017). "Consumers' attitudes on carbon footprint labelling: results of the SUSDIET project," Thünen Working Paper, No. 78 (Braunschweig: Johann Heinrich von Thünen Institute, Federal Research Institute for Rural Areas, Forestry and Fisheries), 62. https://EconPapers.repec. org/RePEc:zbw:jhtiwp:78 (accessed May 12, 2020).

Frank, S., Havlík, P., Stehfest, E., van Meijl, H., Witzke, P., Peres-Dominguez, I., et al. (2019). Agricultural non- $\mathrm{CO}_{2}$ emission reduction potential in the context of the $1.5{ }^{\circ} \mathrm{C}$ target. Nat. Clim. Change 9, 66-72. doi: $10.1038 / \mathrm{s} 41558-018-0358-8$

Fujimori, S., Hasegawa, T., Rogelj, J., Su, X., Havlik, P., and Krey, V. (2018). Inclusive climate change mitigation and food security policy under $1.5^{\circ} \mathrm{C}$ climate goal. Environ. Res. Lett. 13:074033. doi: 10.1088/1748-9326/aad0f7

Gerber, P. J., Steinfeld, H., Henderson, B., Mottet, A., Opio, C., Dijkman, J., et al. (2013). Tackling Climate Change Through Livestock - A Global Assessment of Emissions and Mitigation Opportunities. Rome: Food and Agriculture Organization, 139.

Gil, J. D. B., Daioglou, V., van Ittersum, M., Reidsman, P., Doelman, J. C., van Middelaar, C. E., et al. (2019). Reconciling global sustainability targets and local action for food production and climate change mitigation. Global Environ. Change 59:101983. doi: 10.1016/j.gloenvcha.2019.10 1983

Grafton, R. Q., Williams, J., Perry, C. J., Molle, F., Ringler, C., Steduto, P., et al. (2018). The paradox of irrigation efficiency. Science 361, 748-750. doi: $10.1126 /$ science.aat 9314

GRAIN and the Institute for Agriculture and Trade Policy (2018). Emissions Impossible: How Big Meat and Dairy Are Heating Up the Planet. Available online at: https://www.grain.org/article/entries/5976-emissions-impossible-how-bigmeat-and-dairy-are-heating-up-the-planet (accessed December 12, 2019).
Grewer, U., Nash, J., Gurwick, N., Bockel, L., Galford, G., Richards, M., et al. (2018). Analyzing the greenhouse gas impact potential of smallholder development actions across a global food security program. Environ. Res. Lett. 13:044003. doi: 10.1088/1748-9326/aab0b0

Hasegawa, T., Fujimori, S., Havlík, P., Valin, H., Bodirsky, B. L., Doelman, J. C., et al. (2018). Risk of increased food insecurity under stringent global climate change mitigation policy. Nat. Clim. Change 8, 699-703. doi: 10.1038/s41558-018-0230-x

Henderson, B., and Frezal, C. (2019). International Scan of GHG Mitigation Policies in Agriculture. Report prepared for New Zealand's Interim Climate Change Committee. Wellington: Interim Climate Change Committee (ICCC), 81.

Hristov, A. N., Oh, J., Giallongo, F., Frederick, T. Q., Harper, M. T., Weeks, H. L., et al. (2015). An inhibitor persistently decreased enteric methane emission from dairy cows with no negative effect on milk production. Proc. Natl. Acad. Sci. U.S.A. 112, 10663-10668. doi: 10.1073/pnas. 1504124112

Huppmann, D., Rogelj, J., Kriegler, E., Krey, V., and Riahi, K. (2018). A new scenario resource for intergrated $1.5^{\circ} \mathrm{C}$ research. Nat. Clim. Change 8, 1027-1032. doi: 10.1038/s41558-018-0317-4

Hurlbert, M., Krishnaswamy, J., Davin, E., Johnson, F. X., Mena, C. F., Morton, J., et al. (2019). "Chapter 7: Risk management and decision making in relation to sustainable development," in Climate Change and Land: An IPCC Special Report on Climate Change, Desertification, Land Degradation, Sustainable Land Management, Food Security, and Greenhouse Gas Fluxes in Terrestrial Ecosystems, eds P. R. Shukla, J. Skea, E. Calvo Buendia, V. Masson-Delmotte, H.-O. Pörtner, D.C. Roberts, P. Zhai, R. Slade, S. Connors, R. van Diemen, M. Ferrat, E. Haughey, S. Luz, S. Neogi, M. Pathak, J. Petzold, J. Portugal Pereira, P. Vyas, E. Huntley, K. Kissick, M. Belkacemi, and J. Malley (Geneva: Intergovernmental Panel on Climate Change (IPCC)).

ICCC (2019). Action on Agricultural Emissions: Evidence, Analysis and Recommendations. Wellington: Interim Climate Change Committee, 148. Available online at: https://www.iccc.mfe.govt.nz/what-we-do/agriculture/ agriculture-inquiry-final-report/action-agricultural-emissions/ (accessed December 12, 2019).

IPCC (2018). "Global Warming of $1.5^{\circ} \mathrm{C}$," in An IPCC Special Report on the Impacts of Global Warming of $1.5^{\circ} \mathrm{C}$ Above Pre-Industrial Levels and Related Global Greenhouse Gas Emission Pathways, in the Context of Strengthening the Global Response to the Threat of Climate Change, Sustainable Development, and Efforts to Eradicate Poverty, eds V. Masson-Delmotte, P. Zhai, H.-O. Pörtner, D. Roberts, J. Skea, P.R. Shukla, A. Pirani, W. Moufouma-Okia, C. Péan, R. Pidcock, S. Connors, J.B.R. Matthews, Y. Chen, X. Zhou, M.I. Gomis, E. Lonnoy, T. Maycock, M. Tignor, and T. Waterfield (Geneva: Intergovernmental Panel on Climate Change).

IPCC (2019). "Summary for Policymakers," in Climate Change and Land: An IPCC Special Report on Climate Change, Desertification, Land Degradation, Sustainable Land Management, Food Security, and Greenhouse Gas Fluxes in Terrestrial Ecosystems. eds P.R. Shukla, J. Skea, E. Calvo Buendia, V. MassonDelmotte, H.- O. Pörtner, D. C. Roberts, P. Zhai, R. Slade, S. Connors, R. van Diemen, M. Ferrat, E. Haughey, S. Luz, S. Neogi, M. Pathak, J. Petzold, J. Portugal Pereira, P. Vyas, E. Huntley, K. Kissick, M. Belkacemi, and J. Malley (Geneva: Intergovernmental Panel on Climate Change (IPCC)).

Joint Committee on Climate Action (2019). Climate Change: A Cross-Party Consensus for Action. Report of the Joint Committee on Climate Action. Dublin: Tithe An Oireachtais - Houses of the Oireachtas, 150. Available online at: https://www.oireachtas.ie/en/committees/32/climate-action/ (accessed December 12, 2019).

Kriegler, E., Edmonds, J., Hallegatte, S., Ebi, K. L., Kram, T., Riahi, K., et al. (2014). A new scenario framework for climate change research: the concept of shared climate policy assumptions. Clim. Change 122, 401-414. doi: 10.1007/s10584-0130971-5

Loboguerrero, A. M., Campbell, B., Cooper, P., Hansen, J. W., Rosenstock, T., and Wollenberg, E. (2019). Food and earth systems: priorities for climate change adaptation and mitigation for agriculture and food systems. Sustainability 11:1372. doi: 10.3390/su11051372

Lynch, J., and Pierrehumbert, R. (2019). Climate impacts of cultured meat and beef cattle. Front. Sust. Food Syst. 3:5. doi: 10.3389/fsufs.2019.00005 
Mbow, C., Rosenzweig, C., Barioni, L. G., Benton, T. G., Herrero, M., Krishnapillai, M., et al. (2019). "Chapter 5: Food security," in Climate Change and Land: An IPCC Special Report on Climate Change, Desertification, Land Degradation, Sustainable Land Management, Food Security, and Greenhouse Gas Fluxes in Terrestrial Ecosystems. eds P.R. Shukla, J. Skea, E. Calvo Buendia, V. MassonDelmotte, H.- O. Pörtner, D. C. Roberts, P. Zhai, R. Slade, S. Connors, R. van Diemen, M. Ferrat, E. Haughey, S. Luz, S. Neogi, M. Pathak, J. Petzold, J. Portugal Pereira, P. Vyas, E. Huntley, K. Kissick, M. Belkacemi, and J. Malley (Geneva: Intergovernmental Panel on Climate Change (IPCC)).

Meinshausen, M., Meinshausen, N., Hare, W., Raper, S. C. B., Frieler, K., Knutti, D., et al. (2009). Greenhouse-gas emission targets for limiting global warming to $2^{\circ} \mathrm{C}$. Nature $458,1158-1162$. doi: $10.1038 /$ nature 08017

Meinshausen, M., Raper, S. C. B., and Wigley, T. M. L. (2011). Emulating coupled atmosphere-ocean and carbon cycle models with a simpler model, MAGICC6 - part 1: model description and calibration. Atmos. Chem. Phys. 11, 1417-1456. doi: 10.5194/acp-11-1417-2011

MfE (2018). New Zealand's Greenhouse Gas Inventory 1990-2016. Publication ME 1351. Wellington: Ministry for the Environment, 519. Available online at: https://www.mfe.govt.nz/publications/climate-change/new-zealandsgreenhouse-gas-inventory-1990\%E2\%80\%932016 (accessed December 12, 2019).

Morice, C. P., Kennedy, J. J., Rayner, N. A., and Jones, P. D. (2012). Quantifying uncertainties in global and regional temperature change using an ensemble of observational estimates: the HadCRUT4 data set. J. Geophys. Res. Atmospheres 117:D08101. doi: 10.1029/2011JD017187

Muetzel, S., Lowe, K., Janssen, P. H., Pacheco, D., Bird, N., Walker, N., et al. (2019). "Towards the application of 3-nitrooxypropanol in pastoral farming systems," in Abstract Retrieved from the Proceedings of the 7th GGAA - Greenhouse Gas and Animal Agriculture Conference (Iguassu Falls), 81.

OECD (2019a). The Impacts of Climate Change Mitigation Policies in Agriculture: Finding the Balance. COM/TAD/CA/ENV/EPOC(2019)9. Paris: Organisation for Economic Cooperation and Development (OECD), 22. Available online at: http://www.oecd.org/officialdocuments/publicdisplaydocumentpdf/?cote= COM/TAD/CA/ENV/EPOC(2019)9/FINALanddocLanguage=En (accessed December 12, 2019).

OECD (2019b). Enhancing the Mitigation of Climate Change Though Agriculture. Paris: Organisation for Economic Cooperation and Development (OECD). Available online at: https://www.oecd-ilibrary.org/content/publication/ e9a79226-en (accessed December 12, 2019).

O’Neill, B. C., Kriegler, E., Ebi, K. L., Kemp-Benedict, E., Riahi, K., Rothman, D. S., et al. (2015). The roads ahead: narratives for shared socioeconomic pathways describing world futures in the 21st century. Global Environ. Change 42, 169-180. doi: 10.1016/j.gloenvcha.2015.01.004

Phalan, B. (2018). What have we learned from the land sparing-sharing model? Sustainability 10:1760. doi: 10.3390/su10061760

Popp, A., Calvin, K., Fujimori, S., Havlik, P., Humpenoder, F., Stehfest, E., et al. (2017). Land-use futures in the shared socio-economic pathways. Global Enviro. Change 42, 331-345. doi: 10.1016/j.gloenvcha.2016.10.002

Rapsomanikis, G. (2015). The Economic Lives of Smallholder Farmers. An Analysis Based on Household Data from Nine Countries. Rome: Food and Agriculture Organisation of the United Nations (FAO), 48. Available online at: http://www. fao.org/3/a-i5251e.pdf (accessed December 12, 2019).

Reisinger, A., Clark, H., Abercrombie, R., and Aspin, M., ettema, P., Harris M, et al. (2018). Future Options to Reduce Biological GHG Emissions OnFarm: Critical Assumptions and National-Scale Impact. Report prepared for the Biological Emissions Reference Group. Wellington: Ministry for Primary Industries, 80. Available online at: https://www.mpi.govt.nz/dmsdocument/ 32128/send (accessed December 12, 2019).

Riahi, K., van Vuuren, D. P., Kriegler, E., Edmonds, J., O’Neill, B. C., Fujimori, S., et al. (2017). The Shared Socioeconomic Pathways and their energy, land use, and greenhouse gas emissions implications: an overview. Global Environ. Change 42, 153-168. doi: 10.1016/j.gloenvcha.2016.05.009

Richards, M. (2019). National Plans to Address Adaptation and Mitigation in Agriculture: An Analysis of Nationally Determined Contributions. CCAFS dataset. Wageningen: CGIAR Research Program on Climate Change, Agriculture and Food Security (CCAFS). Available online at: https://hdl.handle. net/10568/101189 (accessed May 12, 2020).
Robinson, T. P., Thornton, P. K., and Franceschini, G. (2011). Global Livestock Production Systems. Rome: Food and Agriculture Organization of the United Nations (FAO) and International Livestock Research Institute (ILRI), 152. Available online at: http://www.fao.org/3/i2414e/i2414e00.htm (accessed December 12, 2019).

Rogelj, J., Reisinger, A., McCollum, D. L., Knutti, R., Riahi, K., and Meinshausen, M. (2015). Mitigation choices impact carbon budget size compatible with low temperature goals. Environ. Res. Lett. 10:075003. doi: 10.1088/1748-9326/10/7/075003

Rogelj, J., Shindell, D., Jiang, K., Fifita, S., Forster, P., Ginzburg, V., et al. (2018). "Mitigation pathways compatible with $1.5^{\circ} \mathrm{C}$ in the context of sustainable development," in Global Warming of $1.5^{\circ} \mathrm{C}$. An IPCC Special Report on the Impacts of Global Warming of $1.5^{\circ} \mathrm{C}$ Above Pre-Industrial Levels and Related Global Greenhouse Gas Emission Pathways, in the Context of Strengthening the Global Response to the Threat of Climate Change, Sustainable Development, and Efforts to Eradicate Poverty, eds V. Masson-Delmotte, P. Zhai, H.-O. Pörtner, D. Roberts, J. Skea, P.R. Shukla, A. Pirani, W. Moufouma-Okia, C. Péan, R. Pidcock, S. Connors, J.B.R. Matthews, Y. Chen, X. Zhou, M.I. Gomis, E. Lonnoy, T. Maycock, M. Tignor, and T. Waterfield (Geneva: Intergovernmental Panel on Climate Change), 93-174.

Roos, E., Bajzelj, B., Smith, P., Patel, M., Little, D., and Garnett, T. (2017). Greedy or needy? Land use and climate impacts of food in 2050 under different livestock systems. Global Environ. Change 47, 1-12. doi: 10.1016/j.gloenvcha.2017.09.001

Roy, J., Tschakert, P., Waisman, H., Halim, S. A., Antwi-Agyei, P., Dasgupta, P., et al. (2018). "Sustainable development, poverty eradication and reducing inequalities," in Global Warming of $1.5^{\circ} \mathrm{C}$. An IPCC Special Report on the Impacts of Global Warming of $1.5^{\circ} \mathrm{C}$ Above Pre-Industrial Levels and Related Global Greenhouse Gas Emission Pathways, in the Context of Strengthening the Global Response to the Threat of Climate Change, Sustainable Development, and Efforts to Eradicate Poverty, eds V. MassonDelmotte, P. Zhai, H.-O. Pörtner, D. Roberts, J. Skea, P.R. Shukla, A. Pirani, W. Moufouma-Okia, C. Péan, R. Pidcock, S. Connors, J.B.R. Matthews, Y. Chen, X. Zhou, M.I. Gomis, E. Lonnoy, T. Maycock, M. Tignor, and T. Waterfield (Geneva: Intergovernmental Panel on Climate Change), 445-538.

Shafer, S., Walthall, C., Franzluebbers, A., Scholten, M., Clark, H., Reisinger A., et al. (2011). Emergence of the global research alliance on agricultural greenhouse gases. Carbon Manag. 2, 209-214. doi: 10.4155/cmt.11.26

Stephens, N., Di Silvio, L., Dunsford, I., Ellis, M., Glencross, A., and Sexton, A. (2018). Bringing cultured meat to market: technical, socio-political, and regulatory challenges in cellular agriculture. Trends Food Sci. Technol. 78, 155-166. doi: 10.1016/j.tifs.2018.04.010

Tadesse, G., Algieri, B., Kalkuhl, M., and von Braun, J. (2014). Drivers and triggers of international food price spikes and volatility. Food Policy 47, 117-128. doi: 10.1016/j.foodpol.2013.08.014

Valdivia, R., Antle, J., Rosenzweig, C., Ruane, A. C., Vervoort, J., Ashfaq, M., et al. (2015). "Representative agricultural pathways and scenarios for regional integrated assessment of climate change impacts, vulnerability, and adaptation," in Handbook of Climate Change and Agroecosystems: Impacts, Adaptation and Mitigation, eds C. Rosenzweig and D. Hillel (London: Imperial College Press), 101-145. doi: 10.1142/9781783265640_0005

Vermeulen, S. J., Aggarwal, P. K., Ainslie, A., Angelone, C., Campbell, B. M., Challinor, A. J., et al. (2012). Options for support to agriculture and food security under climate change. Environ. Sci. Policy 15, 136-144. doi: 10.1016/j.envsci.2011.09.003

Vermeulen, S. J., and Wollenberg, E. K. (2017). A Rough Estimate of the Proportion of Global Emissions from Agriculture Due to Smallholders. CCAFS info note. Available online at: https://ccafs.cgiar.org/publications/rough-estimateproportion-global-emissions-agriculture-due-smallholders\#.XfFhLOgzaUk (accessed December 12, 2019).

Wedlock, D. N., Janssen, P. H., Leahy, S. C., Shu, D., and Buddle, B. M. (2013). Progress in the development of vaccines against rumen methanogens. Animal 7, 244-252. doi: 10.1017/S1751731113000682

Wollenberg, E. (2017). The mitigation pillar of Climate-Smart Agriculture (CSA): targets and options. Agric. Develop. 30, 19-22.

Wollenberg, E., Richards, M., Smith, P., Havlik, P., Obersteiner, M., Tubiello, F. N., et al. (2016). Reducing emissions from agriculture to meet 
the $2^{\circ} \mathrm{C}$ target. Global Change Biology 22, 3859-3864. doi: 10.1111/gcb. 13340

Yu, Y., Stomph, T. J., Makowski, D., and van der Werf, W. (2015). Temporal niche differentiation increases the land equivalent ratio of annual intercrops: a meta-analysis. Field Crops Res. 184:133-144. doi: 10.1016/j.fcr.2015. 09.010

Zomer, R. J., Neufeldt, H., Xu, J., Ahrends, A., Bossio, D., Trabucco, A., et al. (2016). Global tree cover and biomass carbon on agricultural land: the contribution of agroforestry to global and national carbon budgets. Sci. Rep. 6:29987. doi: 10.1038/ srep 29987
Conflict of Interest: The authors declare that the research was conducted in the absence of any commercial or financial relationships that could be construed as a potential conflict of interest.

Copyright (c) 2020 Leahy, Clark and Reisinger. This is an open-access article distributed under the terms of the Creative Commons Attribution License (CC BY). The use, distribution or reproduction in other forums is permitted, provided the original author(s) and the copyright owner(s) are credited and that the original publication in this journal is cited, in accordance with accepted academic practice. No use, distribution or reproduction is permitted which does not comply with these terms. 